\title{
Study of the Effectiveness of Ledipasvir/Sofosbuvir Treatment Regimen in Patients with Chronic Hepatitis C Virus (HCV) Infection
}

\author{
SHAMARDAN E.S. BAZEED, M.D.; ALI A. GHWEIL, Ph.D.; HEBA A. OSMAN, M.D. and \\ MOHAMMED A. MOHAMMED, M.Sc.
}

The Department of Gastroenterology, Hepatology and Tropical Medicine, SVU Faculty of Medicine \& Hospitals, Qena, Egypt

\begin{abstract}
Background: Treatment of Hepatitis C Virus (HCV) infection had significantly changed during the last few years. The combination of Sofosbuvir and Ledipasvir (SOF/LDV) has been shown to treat high proportions of patients with $\mathrm{HCV}$.

Aim of Study: The aim of the work was to assess the efficacy and risk factors for failure of SOF/LDV in Egyptian patients with $\mathrm{HCV}$ infection.

Patients and Methods: In this prospective study, 138 patients who were HCV antibody positive and HCV RNA positive by Polymerase Chain Reaction (PCR), aged between 18 and 75 years, were enrolled. The patients assessed demographically, and by laboratory and ultrasound. The patients received daily Sofosbuvir 400mg plus Ledipasvir 90mg for 12 weeks, the primary end point was a sustained virological response at 12 weeks (SVR12) after the end of treatment, determined by quantitative PCR for HCV RNA. The patients were classified into two groups according to SVR12: Responders included 133 patients who had undetectable level of HCV RNA and non-responders included 5 patients who had detectable level of HCV RNA.
\end{abstract}

Results: The overall SVR12 was $96.4 \%$. The response of cirrhotic vs. non-cirrhotic patients was $(80 \%$ vs. 98.4$)$ with statistically significant $p$-value $(p<0.05)$ with specificity $90 \%$ and sensitivity $60 \%$ (odds ratio $=15.125,95 \%$ confidence interval 2.29-99.6, $p<0.05$ ), and the response of naïve vs. experienced patients was $(97.6 \%$ vs. $83.3 \%)$ with statistically significant $p$-value $(p<0.05)$ with specificity $92.5 \%$ and sensitivity $40 \%$ (odds ratio $=8.2,95 \%$ confidence interval $1.22-54.9, p<0.05)$.

Conclusion: Sofosbuvir/Ledipasvir combination for 12 weeks was very effective for chronic $\mathrm{HCV}$ treatment, cirrhosis and treatment-experienced patients were associated with decreased likelihood of SVR.

Key Words: Sofosbuvir and Ledipasvir - HCV - Sustained Virological Response (SVR).

Correspondence to: Dr. Mohammed A.Mohammed, E-Mail: Hellotomorrowmohammed@gmail.com

\section{Introduction}

CHRONIC hepatitis C infection is a noteworthy reason for constant liver illness, cirrhosis and liver disease just as a vital sign for liver transplantation [1].Internationally, it was estimated that more than 185 million people had hepatitis $\mathrm{C}$ virus antibodies [2].In Egypt, where approximately $11 \%$ of people, or 8 million persons, are certain for anti-HCV [3] In Egypt, genotype $4 \mathrm{HCV}$ is especially common, and about $15 \%$ of the Egyptian populace is infected with this subtype [4].

The treatment of HCV has experienced a great change with the presentation of Direct Acting Antiviral agents (DAAs). This methodology has realized extraordinary cure rates with Sustained Virologic Response (SVR) surpassing 90\%, with better decency, limited symptoms and brief span of treatment [5].

Further, these drugs have made it workable for patients previously excluded in the interferon (IFN) therapy era, for example, decompensated cirrhosis to be dealt with. The achievement of SVR can bring reversal of decompensation, improved survival rates and decreased requirement for liver transplantation [6].

Since 2011, there has been the advancement of several new regimens of direct acting anti-viral associated with noteworthy improvements in efficacy and decency in treatment of HCV. Annihilation of $\mathrm{HCV}$ is associated with diminished overall morbidity and mortality as well as expanded personal satisfaction and reduced healthcare utilization [7]. Based on the prevalence of infection and accessibility of highly effective direct acting antivirals, treatment is presently recommended for all patients with chronic HCV infection. 


\section{Patients and Methods}

From December, 2017, to October, 2018, at Outpatient Clinic of Tropical Medicine Department, Faculty of Medicine, South Valley University Hospitals (Qena Hospitals). We enlisted 138 patients, qualified patients were 128 men and 10 women with age range between 18 and 75 years who had chronic $\mathrm{HCV}$ infection with positive $\mathrm{HCV}$ RNA by PCR and who were treatment naive or treatment experienced. All the patients provided written informed consent. Patients who were coinfected with HIV, pregnant female, patient with child score more than 6 patients, patients with any malignancy and patients with GFR less than $30 \mathrm{ml} /$ minute were excluded.

All patients were exposed to full history taking and clinical examination. Blood samples were gathered from patients and submitted to complete blood picture (CBC), liver profile, serum creatinine, pregnancy test (for females), Alpha-Fetoprotein (AFP), fasting blood glucose level, HBsAg (Hepatitis B surface antigen) and serum HCV RNA PCR (at baseline, at 12 th weeks of treatment and after 12 weeks of end of treatment) all study patients were submitted to screening with Ultrasoundevaluation. Approximately $12 \%$ of the enlisted patients had evidence of cirrhosis, defined by a liver-ultrasonography. We reached patients for screening visits in which they finished screening prerequisites.

\section{Study design:}

In this single-focus, open-label cohort, nonrandomized study, every patient gotten a fixeddose combination tablet including $90 \mathrm{mg}$ of ledipasvir and 400mg of sofosbuvir, controlled orally once day by day. We quantified plasma HCV RNA concentrations utilizing quantitative $\mathrm{HCV}$-PCR before and 12 weeks after treatment.

The end point was the rate of sustained virologic response (SVR12), characterized as the loss of quantifiable HCV RNA in serum, after 12 weeks of treatment finish among all patients who were treated. Quantitative HCV-PCR was estimated utilizing the COBAS TaqMan assay with a lower cutoff of recognition of $15 \mathrm{IU}$.

\section{Statistical analysis:}

The efficacy analysis was based on an intentionto-treat population (all patients who got no less than one portion of study drugs). We determined the extent of patients accomplishing SVR12 after fulfillment of treatment. We did analyses with Statistical Program for Social Science (SPSS) version 20, quantitative data were communicated as mean \pm Standard Deviation (SD). Qualitative data were communicated as frequency and percentage. Baseline clinical and demographic characteristics were compared statistically. The outcome is a categorical variable, so is presented as frequency and percentage. All statistical tests were considered significant at $\alpha$ level less than 0.05 .

\section{Results}

\section{Baseline characteristics:}

Out of 138 patients, there was $128(92.8 \%)$ males, $129(93.5 \%)$ patientswere less than 60 years old, $12(8.7 \%)$ patients were experienced to previous anti HCV treatment, $17(12.3 \%)$ patients were diabetic, $16(11.6 \%)$ patients were cirrhotic by ultrasound. The demographic data of the patients.

\section{Efficacy:}

The general SVR for all patients was $96.4 \%$. This result indicates that ledipasvir and sofosbuvir was very effective. Among patients with cirrhosis, the rate of SVR was $80 \%$ the respective rates among non-cirrhotic patients were $98.4 \%$. The difference between the rates of response among cirrhotic and non-cirrhotic patients was significant $(p=0.009)$, with Specificity $91 \%$ and sensitivity $60 \%$. Also, among treatment-experienced patients, the rate of SVR was $83.3 \%$ the respective rates among naïve patients was $97.6 \%$. The difference between the rates of response among individuals with and without cirrhosis was significant $(p=0.03)$ and specificity $92.5 \%$ and sensitivity $40 \%$.

\section{Discussion}

The results of this study suggest that an IFNand RBV-free regimen of ledipasvir/sofosbuvir for 12 weeks is very successful. $96.4 \%$ percent of patients achieved the endpoint of SVR12. In the current study, we meant to assess efficacy of Ledipasvir/sofosbuvir treatment regimen for 12 weeks in Egyptian individuals with Chronic Hepatitis C virus and detection of risk factors of failure of treatment regimen. Our study results show that the general Sustained Virological Response (SVR) was $96.4 \%$ (133/138) patients. Response rates were significantly lower in cirrhotic patients compared to non-cirrhotic ( $80 \%$ vs. 98.4 ), also SVR rates were significantly lower in treatment experienced patients compared to treatment naïve patients (83.3\% vs. $97.6 \%)$ and thus, association between cirrhosis and earlier treatment failure (TE) and SVR12 was observed. Therefore, both associated with decreased likelihood of SVR. Our overall SVR result is comparable to SVR rates in practi- 
cally every one of the studies that performed to assess LDV/SOF efficacy in chronic HCV treatment. In the LONESTAR, where [8] reported SVR12 rates $>95 \%$ among all treatment arms treated with LDV/SOF for 8 or 12 weeks. Likewise, in the ELECTRON trial, [9], reported SVR rate of $>92 \%$. The efficacy and safety of LDV/SOF FDC were also evaluated in many trials. In ION-1 trial, [10], reported SVR rates of treatment-innocent patients with GT1 infection, received LDV/SOF with or without RBV for 12 or 24 weeks ran from 97 to $99 \%$ over all groups. In the ION-3 [11], reported that SVR was 95\% (95\% CI, 92-98\%) for 12 weeks of ledipasvir/sofosbuvir [12], reported that SVR rates extended from 94 to $96 \%$ with 12 weeks of LDV/SOF therapy (with or without RBV). Also, [13], in his small open-label single-arm study, SVR12 rate was $93 \%$ (41 of $44 ; 95 \%$ confidence interval, 81-99). Our SVR rates in cirrhotic patients and treatment-experienced patients were $80 \%$ and 83.3 respectively.

This was supported by ION-2 trial, as [10], reported that in the 12-week treatment gatherings, patients with cirrhosis had unobtrusively lower rates of response (86\% with ledipasvir-sofosbuvir and $82 \%$ with ledipasvir-sofosbuvir in addition to ribavirin) than did non-cirrhotic individuals (95 and $100 \%$, respectively). Also, Reddy et al., reported in his study that overall SVR was $96 \%$, although previously treated patients receiving 12 weeks of LDV-SOF without RBV had an SVR12 rate of 90\%. Likewise, in the ELECTRON trial, [9], reported that among cirrhotic earlier invalid responders, SVR12 was accompliahed by nine (100\%) of those receiving LDV/SOF plus RBV and seven (70\%) of those receiving LDV/SOF without RBV. Also, in HCV-TARGET study, [14], reported that one of the factors that predicted SVR12 was absence of cirrhosis [15], identified previous treatment failure as possible predictor of SVR12 failure. Recently, [16] did not recommend LDV/SOF for treatment experienced patients with GT4.

But many studies reported higher SVR rates in these patients as, [17], reported in his study in Egypt, that among interferon-experienced patients, SVR rates were $94 \%$ for those receiving 12 weeks of LDV/SOF and $100 \%$ for those receiving 12 weeks of LDV/SOF plus ribavirin [18], reported SVR12 rates of $93.3 \%$ of F3 fibrosis, $93.3 \%$ of compensated cirrhotic and $89.6 \%$ of the decompensated cirrhotic.

The main limitation of this study is its sample size, which makes subgroup comparisons difficult. Therefore, the SVR rates saw in some standard subgroups, for example patients with cirrhosis, ought to be translated to some degree with alert due to relatively low patient numbers and lack of studypower.

In summary, Ledipasvir/sofosbuvir for 12 weeks was a profoundly compelling treatment option for treatment-naive non-cirrhotic chronic HCV patients, also cirrhosis and treatment-experienced patients showed decrease in the SVR rate.

\section{References}

1- MARLEEN H.M. HESSEL, ADAM F. COHEN and RISSMANN R.: New Drug Mechanism Sofosbuvir and daclatasvir. Br. J. Clin. Pharmacol., (82) 878-9, 2016.

2- MOHD HANAFIAH K., GROEGER J., FLAXMAN A.D. and WIERSMA S.T.: Global epidemiology of hepatitis C virus infection: New estimates of age-specific antibody to HCV seroprevalence. Hepatology, 57: 1333, 2013.

3- BREBAN R., DOSS W., ESMAT G., ELSAYED M., HELLARD M., AYSCUE P., et al.: Towards realistic estimates of HCV incidence in Egypt. J. Viral Hepat., 20: 294-6, 2013.

4- GOWER E., ESTES C., BLACH S., RAZAVI-SHEARER K. and RAZAVI H.: Global epidemiology and genotype distribution of the hepatitis $\mathrm{C}$ virus infection. J. Hepatol., 61 (suppl 1): S45-57, 2014.

5- BABATIN M.A., ALGHAMDI A.S., et al.: Efficacy and Safety of Simeprevir or Daclatasvir in Combination with Sofosbuvir for the Treatment of Hepatitis C Genotype 4 Infection. J. Clin. Gastroenterol., doi: 10.1097/MCG. 0000000000000 896, 2017.

6- KANDA T.: Interferon-free treatment for $\mathrm{HCV}$-infected patients with decompensated cirrhosis. Hepatol. Int., 11 (1): 38-44, 2017.

7- YOUNOSSI Z.M., STEPANOVA M., SULKOWSKI M., NAGGIE S., HENRY L. and HUNT S.: Sofosbuvir and ledipasvir improve patient-reported outcomes in patients co-infected with hepatitis $\mathrm{C}$ and human immunodeficiency virus. J. Viral Hepat., 23: 857-86, 2016.

8- LAWITZ E., LANDIS C.S., MALIAKKAL B.J., BONACINI M., ORTIZ-LASANTA G., ZHANG J., et al.: Safety and efficacy of treatment with once-daily ledipasvir/ sofosbuvir (90/400mg) for 12 weeks in genotype $1 \mathrm{HCV}$ infected patients with severe renal impairment. Hepatology, 66: 848A, 2017.

9- GANE E.J., STEDMAN C.A., HYLAND R.H., et al.: Efficacy of nucleotide polymerase inhibitor sofosbuvir plus the NS5A inhibitor ledipasvir or the NS5B nonnucleoside inhibitor GS-9669 against HCV genotype 1 infection. Gastroenterology, 146: 736-43e1, 2014.

10- AFDHAL N., ZEUZEM S., KWO P., et al.: Ion-1, Investigators. "Ledipasvir and sofosbuvir for untreated HCV genotype 1 infection". New England Journal of Medicine. 370 (20): 1889-98, 2014.

11- KOWDLEY K.V., GORDON S.C., REDDY K.R., et al.: (May: ION-3 Investigators. N. Engl. J. Med., 15; 370 (20), 2014. 
12- MIZOKAMI M., YOKOSUKA O., TAKEHARA T., SAKAMOTO N., KORENAGA M., MOCHIZUKI H., et al.: Ledipasvir and sofosbuvir fixed-dose combination with and without ribavirin for 12 weeks in treatmentnaive and previously treated Japanese patients with genotype 1 hepatitis C: An open-label, randomised, phase 3 trial. Lancet Infect Dis., 15: 645-53, 2015.

13- ABERGEL A., et al.: Ledipasvir/sofosbuvir treatment results in high SVR rates in patients with chronic genotype 4 and 5 HCV infection. J. Hepatol., 62 (Suppl 2): S219S220, 2015 .

14- TERRAULT N., ZEUZEM S., et al.: Effectiveness of LedipasvirSofosbuvir Combination in Patients with Hepatitis C Virus Infection and Factors Associated with Sustained Virologic Response. Gastroenterology, 151 (6): pp. 1131-40.e5, 2016.

15- JANSEN J.W., POWDERLY G.M. and LINNEMAN T.W.: Identification of predictors for treatment failure in hepatitis $\mathrm{C}$ virus patients treated with ledipasvir and sofosbuvir. Ann. Pharmacother., 51 (7): 543-7, 2017.
16- EASLRecommendationson Treatment of Hepatitis C: DOI: https://doi.org/10.1016/j.jhep.2018 . 03.026, 2018.

17- SHIHA G., ESMAT G., HASSANY M., et al.: Ledipasvir/ sofosbuvir with or without ribavirin for 8 or 12 weeks for the treatment of HCV genotype 4 infection: Results from a randomized phase III study in Egypt Gut Published Online First: 17 April. doi: 10. 1 136/gutjnl-2017-315906, 2018.

18- SANAI F., ALTRAIF I., ALSWAT K., ALZANBAGI A., BABATIN M., ALMOUSA A., et al.: Real life efficacy of ledipasvir/sofosbuvir in hepatitis C genotype 4-infected patients with advanced liver fibrosis and decompensated cirrhosis. Journal of Infection, 76 (6): 536-42. doi: 10.1016/ j.jinf.2018.04.001, 2018.

19- REDDY K., BOURLIÈRE M., et al.: Ledipasvir and sofosbuvir in patients with genotype 1 hepatitis $\mathrm{C}$ virus infection and compensated cirrhosis: An integrated safety and efficacy analysis. Hepatology, 62 (1), pp. 79-86, 2015.

\section{دراسة فاعلية الليديباسفير/سوفوسبوفير في علاج المرضى المصابين بعدوى إلتهاب الكبد الوبائى}

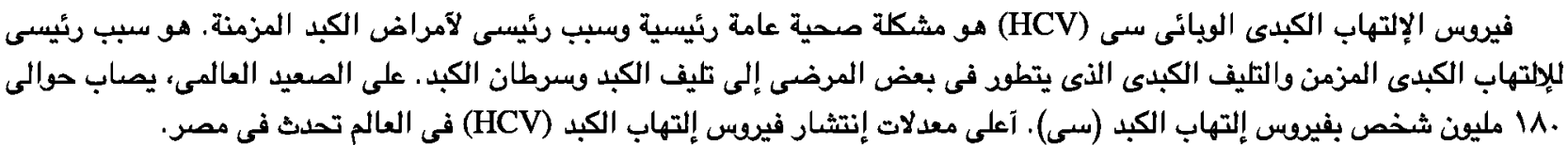

الهدف الرئيسى للعلاج HCV هو تحقيق الإستجابة الفيروبية المستدامة، وهى > HCV RNA الصد الآدنى من الكمية التى يمكن تحديدها

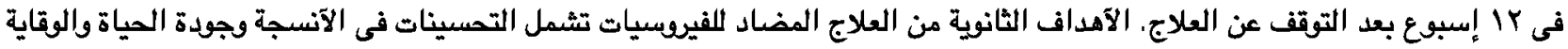
من سرطان الخلايا الكبدية.

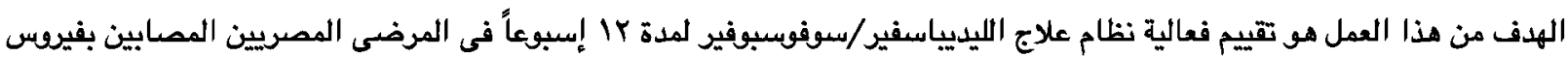

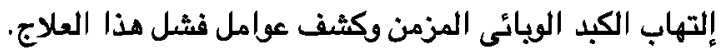

تم تسجيل ^^זا مريضاً بإلتهاب الكبد الوبائى المزمن في الدراسة الحالية، تم إعطاء المرضى جرعة يومية واحدة من Sofosbuvir ( . .عملغ)

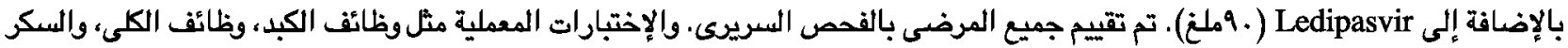
في الدم. وإجراء التصوير بالموجات فوق الصوتية اللبطن.

$$
\text { تم تقييم الإستجابة الفيروبية المستدامة عن طريق PCR بعد إنتهاء العلاج. }
$$

كانت الإستجابة الفيروسية المستدامة لكل الحالات ع .79٪. كانت إستجابة مرضى التليف الكبلى مقابل المرضى الذين ليس لديهم تليف

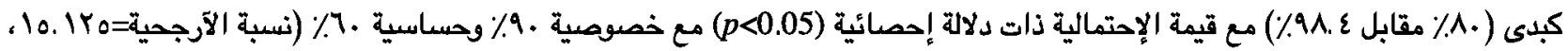

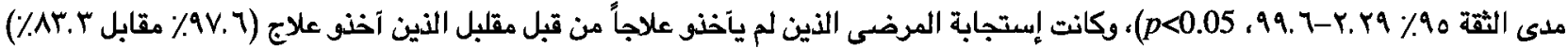

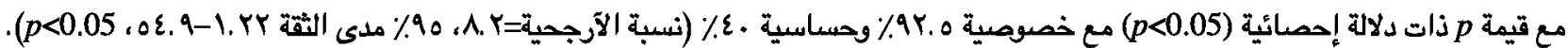

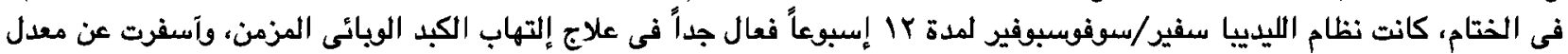

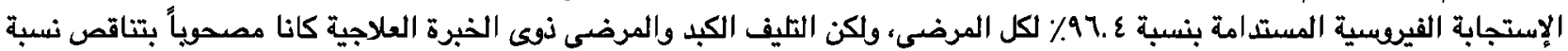

